\title{
CRIMES CONTRA LGBTS NO BRASIL E O DISCURSO DO ESTADO PELOS ÓRGÃOS DE SEGURANÇA PÚBLICA E JURÍDICOS
}

\section{Valdenízia Bento Peixoto'}

Resumo: Este artigo tem como objetivo analisar quatro assassinatos que envolvem motivação LGBTfóbica com base na intepretação das instituições jurídicas e de segurança pública do Estado brasileiro. As instituições jurídicas contemporâneas, expressão de um Estado democrático, conseguem resguardar, em certa medida, os corpos LGBTs e punir quem os golpeia. Entretanto, tais instituições não são capazes de perceber a violência contra LGBTs como uma construção cultural e histórica na sociedade. Mesmo que haja alguns avanços jurídicos, é fundamental um investimento político, social e cultural contra a discriminação e em favor da diversidade sexual.

Palavras-chave: Violência; abjeção; sexualidades.

\begin{abstract}
This article analyzes four murders involving LGBTphobic motivation based on the interpretation of public security and legal institutions in Brazilian government. Contemporary legal institutions, represented by the democratic state, are able to protect the LGBT individuals to a certain extent, and to punish those who target them. However, legal institutions cannot identify violence towards LGBT people that functions as a cultural and historical construction in society. Even when some improvements are present in the law, it is of paramount importance to invest in political, social and cultural measures against discrimination and in favor of sexual diversity.
\end{abstract}

Keywords: Violence; abjection; sexualities.

\section{Introdução}

Este artigo tem o propósito de analisar criticamente o fenômeno da violência contra lésbicas, gays, bissexuais, travestis e transexuais (LGBT) no Brasil a partir da relação de abjeção que o(a) agressor(a) estabelece com os corpos e comportamentos das vítimas. Além disso, intento problematizar como as instituições jurídicas e de segurança pública do Estado

Doutora em Sociologia, Universidade de Brasilia, Brasil. E-mail: val.peixoto@gmail.com. Orcid: 0000-0002-6983-6549 
brasileiro respondem a esse tipo de violência. Para tanto, parto da investigação de processos criminais de quatro assassinatos ocorridos no Brasil, sendo estes de duas travestis, Dalva e Camila; de um garoto de oito anos, Alex Medeiros de Moraes; e do bailarino Igor Xavier. Essas análises foram objeto de minha pesquisa de doutorado, apresentada em março de 2018 ao Programa de Pós-Graduação em Sociologia da Universidade de Brasilia (PEIXOTO, 2018).

Tive acesso aos autos processuais na íntegra nas varas criminais em que os crimes ocorreram, nos estados de Goiás, Rio de Janeiro e Minas Gerais. Os assassinos e condenados foram: Alex Brito Alves da Cruz, Ismael Araújo Dias, Lucas Ronan Correia de Brito e Carlinda de Araújo Santana (assassinos de Dalva e Camila); Alex André Moraes Soeiro (pai e assassino do pequeno Alex); e Ricardo Athayde (assassino de Igor). Narro suas vidas e mortes a partir do que foi coletado nos processos e em algumas poucas reportagens de jornais eletrônicos que noticiaram os crimes na época.

Para a escolha desses casos, elaborei critérios metodológicos para me orientar e, assim, elenquei as seguintes características necessárias para sua seleção: (1) crimes de grande repercussão na mídia impressa e eletrônica; (2) crimes de grande comoção na sociedade regional e nacional; (3) crimes com excesso de crueldade; (4) crimes com julgamento, sentença e condenação; (5) processos criminais com viabilidade de acesso nas instituições jurídicas, tanto operacional quanto de localização geográfica; (6) crimes que não corressem em segredo de justiça; e (7) crimes reconhecidos pela sociedade civil (especialmente movimentos sociais) como de conotação LGBTfóbica.

O assassinato, a hostilização, o menosprezo e a exclusão de LGBTs é algo real e patente na sociedade brasileira, mas também em toda a América Latina. Embora alguns países, como Uruguai e Argentina, bem como o Brasil, possuam legislações e políticas avançadas em termos de direitos LGBT, ainda é o Brasil o país que mais assassina essa população em todo o continente. Além disso, o apogeu conservador que se instalou nos governos deste país contribuíram para o acirramento da violência, assim como para a extinção e diminuição das poucas políticas existentes para tal grupo. $O$ atual governo brasileiro, eleito em 2018, possui um projeto de total vilipêndio contra vidas da população LGBT. É por essas razões que abordarei com exclusividade os casos brasileiros, mas sem perder a perspectiva conjuntural da política de direitos humanos latino-americana. 


\section{Violência contra LGBTs: narrativas sobre vida e morte}

Discorrer sobre os casos relativos a assassinatos e demais crimes de inspiração LGBTfóbica traz à cena questões que perpassam o sentido da vida, ou da sobrevida, desses sujeitos. Tais corpos, que neste momento não existem mais, tiveram uma experiência de vida e morte antagônica àquilo que é social e culturalmente convencionado. Embora suas existências fossem múltiplas, ou seja, viviam em comunidade exercendo diversas funções e atribuições, ainda assim o motivo exclusivo da eliminação de suas vidas foi a vivência de suas sexualidades, impressas em seus corpos que, segundo seus(as) assassinos(as), eram abjetos e impuros, proibidos de permanecerem em sociedade.

Além disso, tem-se um Estado ausente em relação a políticas e compromissos efetivos com as pessoas LGBT, em que o que mais vale é o "motivo torpe" em detrimento de um fenômeno histórico e letal que é o "LGBTcídio". O Estado, ao se esquivar de respostas efetivas para enfrentar essa situação, acaba por ser conivente ou mesmo canalizador das violações. Achille Mbembe (2016) denomina essa posição estatal de "necropolítica", ou seja, um Estado que em determinada condição (guerra, exceção) autoriza o extermínio de quem não é compativel com sua ordem. Sobre esse Estado soberano ele aponta: "Minha preocupação é com aquelas formas de soberania cujo projeto central não é a luta pela autonomia, mas a instrumentalização generalizada da existência humana e a destruição material de corpos humanos e populações" (MBEMBE, 2016, p. 125).

Portanto, apresentar esses corpos numa esfera de suas humanidades não elimina sua condição de corpos dilacerados e que, mesmo em vida, não gozavam de uma condição livre e plena em sua totalidade. Foram corpos presos a uma moral opressora, sendo a todo momento vigiados, punidos e vilipendiados, até o ponto de se tornarem o excremento do ódio de outrem. A morte que lhes foi conferida conota uma explícita abjeção que percorre não só a matéria, mas todo o complexo que envolve a subjetividade.

Dalva, Camila, Alex e Igor não corresponderam a esses padrões socioculturalmente instituídos ao longo de suas vidas. Essas pessoas se distanciaram das padronizações estabelecidas de gênero e sexo e, por isto, foram punidas da forma mais pungente. Não falo da morte ou do assassinato em si, mas da eliminação de suas identidades, que tanto instigaram e potencializaram uma percepção de horror, demonização, monstruosidade e anomalia daqueles(as) que se fazem de sentinelas da moral. 


\section{Dalva e Camila: as travestis}

José Dalvanei Alves Pereira nasceu no dia $1^{\circ}$ de abril de 1975, em Brasilia (DF). Ao assumir a travestilidade, Dalvanei passou a se chamar Dalva. Morava há mais de dez anos no bairro Parque Estrela Dalva IV, também conhecido como Pedregal, no município de Novo Gama (GO).

No processo criminal sobre o assassinato de Dalva e Camila é curioso o apagamento desses nomes. Elas são majoritariamente referenciadas por seus nomes de registro civil ao longo de todo o processo, mesmo tendo todas as testemunhas afirmado que sabiam da travestilidade das vítimas e que estas "se vestiam como mulher". A ambiguidade que Dalva e Camila despertaram na sociedade em relação a sua identidade de gênero foi tão forte que permaneceu mesmo após sua morte. Isso fica evidente quando, em vários trechos do processo e das audiências, as falas de depoentes, do Ministério Público de Goiás (MP-GO) e da juíza do caso permanecem numa confusão operada pela ruptura da padronização de gênero, de modo que ora a vítima era "ele", ora era "ela", ou então era ora chamado de "Dalvanei", e noutro momento de "Dalva". Embora Dalvanei já tivesse desaparecido socialmente há muito tempo, civilmente foi ele o assassinado. $\bigcirc$ paradoxo residente aqui é que, enquanto Dalvanei foi juridicamente morto, foi Dalva quem teve o corpo sucumbido. A violência foi contra Dalva, e foi contra ela a morte brutal, embora, no tribunal, quem aparecesse nos autos fosse Dalvanei.

Dalva era uma grande representação de força e resistência em relação aos limites e às violações enfrentados por travestis, afinal ela tinha conquistado casa própria, um trabalho e uma profissão destoante da maioria das travestis da periferia, que geralmente recorrem à prostituição. Dalva não era um homem que se vestia de mulher: era uma mulher transexual, livre, autônoma, independente e que, por essas características, ultrapassou o limite mais rigoroso das convenções sociais, o limite padronizado de gênero destinado ao masculino.

Já Camila, ao nascer, foi chamada de Luan Fernandes da Silva. Ela morava com Dalva no Pedregal e era bem mais jovem: nasceu em 10 de agosto de 1992, no município de Paulista, na região metropolitana do grande Recife (PE) - portanto tinha 21 anos na data do crime. Camila, assim como Dalva, era um "homem" que se vestia de "mulher", na interpretação das testemunhas do crime. Pouco se sabe de Camila; inclusive, no inquérito passando pela formulação da denúncia apresentada pelo MP-GO, pelo momento das audiências de instrução do processo e por quase todas as demais 
fases de investigação -, foi apenas já perto da metade do tomo processual que se mencionou o nome de registro civil de Camila (GOIÁS, 2013). Até então, ela era nomeada apenas como "Camila de Tal".

Na madrugada do dia 24 de dezembro de 2012, Dalva e Camila, ao retornarem para casa após um forró, foram abordadas pelos vizinhos, que permaneciam na rua bebendo. Estes eram Ismael Araújo Dias (Mael) e os irmãos Alex Brito Alves da Cruz (De noite) e Lucas Ronan Correia de Brito (Bunda). Segundo seu relato, Dalva e Camila, ao passar por eles, os xingaram de bandidos, e esse foi o motivo do assassinato - um xingamento! Os três as seguiram e invadiram sua residência. Dalva e Camila, como narram os réus, estavam bem alcoolizadas, facilitando ainda mais a ação dos agressores. As duas foram brutal e covardemente assassinadas dentro de casa. Tiveram suas cabeças decapitadas e seus corpos carbonizados. As cabeças foram arremessadas em via pública, a uma distância de 300 metros da rua onde moravam. Quanto aos corpos, foram colocados um sobre o outro e lhes atearam fogo, o que provocou um incêndio em toda a casa.

A juíza, na coleta de depoimento de um dos réus, Alex Brito Alves da Cruz, questiona: "O senhor sabia que o Dalvanei era travesti? Camila também? Então, mas eles chegaram e eles que começaram a fazer piadas? Piada do quê? [...] Por que o senhor matou de uma forma tão cruel, assim...?" (informação verbal)2. Esse motivo é destacado pela juíza como extremamente fútil e põe em xeque a veracidade dos fatos, contestando se não foram os assassinos que xingaram as vítimas primeiro, exclusivamente pelo fato de serem travestis. A juíza indaga o mesmo réu, demonstrando que o nível desmesurado da violência pode ser associado ao preconceito contra travestis: "Não é mais fácil o senhor fazer piada da situação deles?". "Por quêe?, retruca o réu. A juíza completa:

Ué, são travestis, não é? Eu não sei se o senhor tem preconceito ou não... Então por que que arrancou as cabeças? [...] Qual a finalidade de queimar os corpos? Já não tinha decapitado? Queimar também? O senhor sabia que as vítimas eram travestis?. (informação verbal) ${ }^{3}$.

Elas foram assassinadas por serem travestis, por se reconhecerem enquanto mulheres, mesmo estando num corpo dito masculino. A identidade de gênero das duas renunciava ao conforto e ao privilégio social que a representação de masculinidade tem estabelecida na sociedade. Ao mesmo tempo

Depoimento (em vídeo) concedido em $1^{\circ}$ de julho de 2013.

3 Depoimento (em vídeo) concedido em 14 de agosto de 2014. 
que "afrontou" a sociedade, colocou-as como alvo daqueles que nutrem a ojeriza e o escárnio contra tudo que foge à norma hegemônica de gênero.

Dalva e Camila foram apagadas da sociedade, e qualquer inscrição que as referisse foi letalmente extinta. Suas cabeças foram arrancadas dos corpos, como se aquelas cabeças com longos cabelos, maquiagem no rosto e brincos longos nas orelhas não pudessem nunca pertencer a um corpo composto por pênis e demais características físicas identificadas como masculinas (GOIÁS, 2013). O sentimento de abjeção é algo relacional entre um "eu" e um "outro", sendo este "outro" construído na ausência da alteridade, mas não só isso.

A percepção do "outro" como desalinhado, desajustado e, portanto, passivel de execração pode ser também originada de uma sensação remota do "eu", relacionada a algo que se identifica de si mesmo no outro, cujo autorreconhecimento é insuportável (KRISTEVA, 2006). Eliminar a existência e qualquer vestígio de inscrição da vida do outro pode ser, em certa medida, o aniquilamento de elementos que esse "eu" não deseja reconhecer em si e que expulsa de forma violenta, materializada no extermínio absoluto dessa representatividade de si expressa no outro.

No entanto, nenhum dos quatro condenados ${ }^{4}$ consegue explicar com precisão o porquê de tamanha violência, qual o motivo para cometer um crime tão bárbaro. Todos declararam não ter nenhum tipo de preconceito contra transexuais, e os irmãos Alex e Lucas inclusive conheciam Dalva da vizinhança desde a adolescência. Nenhum deles externalizou qualquer tipo de rejeição contra transexuais, tampouco localizaram nesse fato um motivo para o cometimento do crime. Para os quatro, tudo não passou de um mal-entendido, de um ato impulsivo mediado pela embriaguez e pelo consumo de drogas, ou de ousadia inapropriada das vítimas, que lhes xingaram de "maloqueiros" e "ladrões". De fato, é incomum alguém se autorreconhecer como "LGBTcida". Da mesma forma, não é comum ouvir ou ver pessoas machistas se autodeclarando misóginas. $\bigcirc$ mesmo se aplica a pessoas racistas, que também não assumem seu ódio contra a raça ou etnia do outro.

\section{O pequeno Alex}

Alex Medeiros de Moraes nasceu em Mossoró (RN), no dia 25 de janeiro de 2006. Seus pais, Alex André Moraes Soeiro e Digna Medeiros,

4 Há uma quarta condenada, Carlinda de Araújo Santana, que é mãe de Ismael. Ela foi condenada como mandante do crime devido a uma "rixa" antiga que tinha com Camila. 
se separaram quando ele ainda era bebê. Em abril de 2013, o garoto Alex, com apenas 7 anos de idade, se mudou do Rio Grande do Norte, onde morava com a mãe, para o Rio de Janeiro, onde passou a morar com o pai. No Rio, o pequeno Alex morava também com a madrasta e mais cinco crianças, sendo dois meios-irmãos e três filhas da madrasta. A casa era localizada na Vila Kennedy, no bairro Bangu, Zona Oeste do Rio de Janeiro.

Alex gostava de brincar, sonhar com coisas alegres, ser desprendido dos padrões morais impostos pela sociedade. De fato, Alex era um garoto diferenciado dos outros, pois não se limitava a vivenciar um mundo onde a padronização de gênero determinasse que ele brincasse com "brinquedos de menino". Rejeitava esse tipo de brinquedo, com os quais o pai insistia em presenteá-lo. Chamava atenção o interesse de Alex por maquiagens, porque, dentro de um universo de gênero heterossexista e binário, esse é um assunto designado para mulheres. Mas Alex, já rompendo esse padrão opressor, conhecia o nome dos produtos, para que serviam e como usá-los. Nada de "anormal" para uma criança, afinal maquiagens e pinturas de rosto podem fazer parte de um mundo cheio de brincadeiras, ludicidade e criatividade artística. A outra paixão do menino era a dança - Alex gostava de "dança do ventre" (RIO DE JANEIRO, 2014).

Era perceptivel que o garoto não tinha nenhum problema em realizar atividades que socialmente são atribuídas às mulheres. Ademais, para repúdio e decepção do pai, o filho gostava de "tarefas domésticas", como lavar louças. Entretanto, até o compartilhamento de simples tarefas domésticas incomodava o pai, pois, para Alex André, lavar pratos e tudo que se refere às atividades do ambiente doméstico deveriam ser obrigação exclusiva das mulheres da casa, ou seja, da esposa e das enteadas.

Apesar disso, atribuir alguns comportamentos e obrigações às mulheres, como "andar rebolando", "lavar louça" e "conhecer maquiagem", faz parte de uma estrutura de dominação e poder que as conduzem a um espaço fútil, pouco importante e desprivilegiado. Neste caso, a concepção do pai e da madrasta de Alex é de que tudo que é considerado "de mulher" é reduzido, desqualificado e menosprezado e, portanto, o comportamento de Alex era totalmente repudiável, pois, como "homenzinho", não poderia se inferiorizar ao patamar de "mulherzinha".

Por tudo isso o pequeno Alex Medeiros de Moraes foi brutalmente assassinado pelo próprio pai, Alex André Moraes Soeiro, pois este não aceitava que o filho agregasse em sua personalidade tantos atributos femininos. 
Não há como afirmar algo sobre sua orientação sexual ou identidade de gênero, mas afirmo que Alex foi assassinado pelo ódio do pai contra homossexuais, por seu escárnio contra tudo que é referente ao gênero feminino e pelo medo insano de que o filho se tornasse futuramente gay ou travesti.

Assim, na manhã do dia 17 de fevereiro de 2014, por volta das 9h, Alex se levantou, tomou café junto com as demais crianças da casa e, no final da manhã, aproximadamente às $11 \mathrm{~h}$, o pai retornou para casa. Foi quando Alex André chamou o filho para cortar o cabelo, e o pequeno Alex o contestou, pois gostava do cabelo um pouco mais comprido. A partir desse momento, os fatos narrados no interior da residência da família tornam-se controversos. A verdade não poderá ser acessada. Porém, algumas informações de documentos contidos no processo criminal, como o laudo de necropsia do pequeno Alex, produzido pelo Instituto Médico Legal (IML), apontam indícios de que a vítima foi espancada na mesma manhã. E por qual motivo? Porque não queria cortar o cabelo!

No entanto, a versão que consta no depoimento de Alex (pai) diz que, após ser contestado pelo filho sobre o corte de cabelo, ele mandou o garoto ir tomar banho para almoçar. $O$ pai depõe que no banheiro Alex sofreu uma queda, o que provocou todas aquelas escoriações e a dilaceração do fígado. Após socorrerem o garoto em casa, este foi dormir, e seu pai saiu para o trabalho. Após algumas horas, a madrasta percebeu que o menino não reagia e resolveu levá-lo à Unidade de Pronto Atendimento (UPA).

A equipe que atendeu Alex (pediatra, enfermeiro e assistente social) declarou que o garoto já havia adentrado à UPA sem vida e, mesmo passando cerca de 40 minutos realizando os procedimentos de ressuscitação, a criança não reagiu. Consta no laudo que havia muitos hematomas pelo corpo, principalmente na região torácica, além de estar bastante emagrecido e com notável aparência de desnutrição grave, o que o fazia parecer ter menos que oito anos de idade.

Conforme o IML, a causa da morte de Alex foi "laceração do fígado", o que ocasionou uma hemorragia intra-abdominal. $\bigcirc$ figado do garoto foi lacerado por uma "ação contundente". No laudo do exame de necropsia do pequeno Alex, lê-se:

[...] presença de escoriações em joelhos e cotovelos e região da escápula direita, áreas de equimose em meio face esquerda e região anterior do tórax, em dorso observa-se várias marcas de lesões anteriores [...]. O corpo exibe escoriações em placas 
irregulares parcialmente recobertas por crosta sero-hemática interessando joelhos e cotovelos, próximo ao pavilhão auricular esquerdo, tórax anterior; e escoriações lineares na região cervical esquerda, equimose pardacenta irregular: face, tórax anterior, supercilio direito, deltoide e punho esquerdos, braço e antebraço direitos, equimose esverdeada e edema pequeno no punho direito e coxa direita, e inúmeras lesões cicatriciais castanhas claras, irregulares atípicas e típicas, nos membros inferiores, tórax posterior e lombar. (RIO DE JANEIRO, 2014, p. 47-48).

Alex possuía um corpo são, sem nenhum problema ou disfunção; porém, - que Alex carregava no corpo era a distinção de algo potencialmente transgressor ante os ditames esquemáticos do binarismo de gênero. Alex escolheu naquela manhã, diante da ordem do pai, a desobediência. Ele escolheu não cortar o cabelo e, por isso, teve a vida eliminada. Esse motivo pode parecer um tanto prosaico para ocasionar a morte de alguém. No entanto, ele representa um amálgama de opressões de diversas formas e intensidades, entre elas o sexismo, a violência geracional, a opressão cultural e a ineficiência do sistema jurídico/punitivo, que à época não tinha sequer um léxico para nomear esse tipo de assassinato ${ }^{5}$.

Por ordem do patriarcado, Alex não conseguiu realizar seus sonhos, nem retirar do seu pequeno corpo o peso da padronização. Seu corpo inerte foi alvejado pela abjeção de um pai que não suportou a possibilidade de ter um filho "parecido com uma mulherzinha".

\section{Igor: gay, bailarino, ator}

Igor Leonardo Lacerda Xavier, bailarino e ator, nasceu em Montes Claros no dia 15 de março de 1972. A homossexualidade de Igor, despontada já na fase juvenil, nunca foi uma questão para a sua familia. Sua mãe, seu pai, suas irmãs e seus irmãos nunca lhe apresentaram os limites heterossexistas da sexualidade, os padrões e as normas patriarcais de gênero ou alguma manifestação de preconceito em relação à sua orientação sexual. Igor sempre pôde exercer sua liberdade e, portanto, era feliz (BRASIL, 2016).

Igor, em vida, representou alguns dos elementos que se aproximam de ideais confluentes com o respeito e com valores de emancipação e liberdade do ser humano. No entanto, mesmo sem uma intencionalidade fática, Igor

\footnotetext{
5 Somente em junho de 2019 o Supremo Tribunal Federal enquadra como crime a discriminação por orientação sexual e identidade de gênero, sendo esta punida pela Lei do Racismo (Lei n7.716/1989), que prevê crimes de discriminação ou preconceito por "raça, cor, etnia, religião e procedência nacional".
} 
provocou um incômodo visceral na ordem estabelecida no âmbito da moral e dos valores mais conservadores com sua cabeleira vermelha, sua dança livre de estereótipos, seu interesse por uma profissão quase que proibida ao universo masculino e, acima de tudo, a sua homossexualidade desvelada, livre e à mostra em casa, na escola, nas ruas, nas praças e nos bares. Como podem todos esses atributos não ofender a mente de quem estabelece para si e para o outro o aprisionamento de tais condições?

Igor voava, saltava, rodopiava e requebrava sem limites, sem tomar conhecimento do paradoxo que provocou diante de seu assassino, Ricardo Athayde. Ricardo, naquela época com 46 anos, herdeiro de uma aristocracia ruralista do estado de Minas Gerais, possivelmente conviveu com a contradição de ao mesmo tempo se ver fascinado, encantado diante da liberdade e beleza do jovem, e não suportar perceber esse sentimento crescendo dentro de si. Não aceitava a irrupção de sentir atração por outro homem e muito menos poderia aceitar brotar um sentimento tão "repugnante", "amoral" e "vergonhoso", que seria o de se apaixonar por um homem gay e, além disso, bailarino.

Como de costume, no dia 28 de fevereiro de 2002, Igor foi ao bar Casa Grande, localizado atrás da Igreja Matriz da cidade de Montes Claros. Ele era frequentador do bar havia alguns anos e, segundo o próprio proprietário do bar, José Pereira Durães, Igor era "uma pessoa amiga de todos e nunca teve atrito com ninguém naquele recinto" (BRASIL, 2016, fl. 34). Ricardo Athayde Vasconcelos também estava no bar. Os dois se encontraram, trocaram algumas palavras e depois seguiram para o apartamento de Ricardo. Chegando lá, Ricardo chamou seu filho Diego para fazer companhia à visita na sala enquanto ia ao banheiro. Ao voltar, o assassino acusou lgor de estar assediando Diego, que na época tinha 18 anos. $\bigcirc$ assédio teria como ponto central o fato de o bailarino ter enlaçado Diego pelo pescoço com um braço, enquanto com a outra mão passara a tocar a genitália do rapaz. $\bigcirc$ pai, ao sair do banheiro e se deparar com essa cena, teria se enfurecido; então foi até o armário da sala, pegou um revólver e uma pistola e disparou cinco tiros contra lgor.

Dos cinco tiros, dois deles foram, conforme os laudos periciais, "tiros de execução", ou seja, um a menos de $30 \mathrm{~cm}$ de distância, e o outro na parte frontal da cabeça (na testa), conhecido como "tiro de misericórdia". Após os disparos, pai e filho trataram de eliminar provas que os levassem à prisão em flagrante. Ricardo e Diego botaram o corpo de Igor no carro 
e o despejaram numa estrada de terra vicinal, distante cerca de $30 \mathrm{~km}$ do perimetro urbano de Montes Claros.

Os suspeitos logo foram identificados como Ricardo e Diego Athayde, pai e filho. Eles se apresentaram ao departamento de polícia cinco e onze dias depois, respectivamente. Tiveram seus depoimentos colhidos e foram liberados logo em seguida. $O$ processo criminal correu com ambos em liberdade.

$\bigcirc$ julgamento dos réus chegou a ser adiado mais de duas vezes, e durante esse período nenhum dos dois acusados ficou preso. Assistidos por uma equipe de defesa de excelência, Ricardo e Diego mantiveram suas vidas com normalidade e tranquilidade. Seus advogados entraram com dezenas de liminares e se resguardavam em lacunas no entendimento jurídico para postergar ao máximo o julgamento e o fluxo regular do processo. Isso se deve ao fato de a família Athayde Vasconcelos ter demasiada influência política e econômica em Montes Claros, como também em todo o estado de Minas Gerais. Mesmo que essa questão não constituísse um motivo jurídico plausível a ser avaliado, é exposta em diversos momentos no processo, pelo Ministério Público e pelo juiz, como um embargo à prisão dos acusados:

De resto, e embora até reconheça que este não seja um argumento de peso no plano jurídico, mas incomoda-nos um pressentimento, uma quase certeza de que, fossem os denunciados de familia humilde, sem tradição, estariam recolhidos à prisão por iniciativas muito anteriores, o que é de lamentar-se. (BRASIL, 2016, fl. 128).

O crime, realmente, abalou a sociedade de Montes Claros a ponto de (além das passeatas e concentrações dos amigos do bailarino vítima na porta do Fórum) ter se tornado tema até nas mais altas rodas sociais, inclusive com insinuações segundo as quais se não houvesse em Montes Claros tantos logradouros públicos com o mesmo sobrenome dos réus, a demonstrar a influência da familia, os mesmos já estariam presos. (BRASIL, 2016, fl. 136, grifos do juiz).

Fica evidente, tanto no teor pragmático dos autos quanto numa análise mais crítica e concreta, que a condição da classe social dos acusados produziu um andamento completamente diferenciado do decurso processual. Não se trata aqui de leis diferenciadas, pois a lei é formalmente igual para todas as pessoas; o que promove a diferença é inexoravelmente a questão da classe social a que os réus pertencem: quem tem mais dinheiro e prestígio político consegue manter-se livre por mais 
tempo, minimizar suas penas, e até mesmo ficar impune ou ser absolvido do crime, como foi o caso de Diego Athayde.

$\bigcirc$ assassinato de Igor Xavier demorou 11 anos para ser julgado e, ao longo desse período, os réus permaneceram em liberdade. $\bigcirc$ julgamento de Ricardo e Diego Athayde ocorreu somente em 27 de agosto de 2013, sendo considerado por diversos veículos de comunicação e pela imprensa nacional como o primeiro julgamento em que aparece a expressão "crime por motivação homofóbica". Mesmo tendo a instância jurídica como aliada ao discurso dos advogados de defesa, alegando que o crime não foi provocado por homofobia, esse caso ficou notadamente conhecido e caracterizado na história da luta dos direitos LGBT como o primeiro julgamento de um crime "homofóbico". A Justiça insistiu em retirar essa qualificadora moral, como mostra o relatório de um juiz que avaliava a transferência do julgamento para o foro de Belo Horizonte:

\begin{abstract}
Aproveitando a popularização do termo homofobia, o discurso dos cultores da memória da vítima é de que o crime foi motivado por homofobia e agitam essa bandeira para defenderem seu anseio de justiça. Tomam como um fato isolado, um crime como muitos que, infelizmente, ocorrem nesta comarca, e querem transformar em uma causa social, provocando grande impacto na percepção dos fatos pela comunidade local, ao arrepio do processo, uma vez que essa propalada motivação não consta na acusação. (BRASIL, 2016, fl.1.200, grifos do juiz).
\end{abstract}

O julgamento foi acompanhado por importantes representantes da luta em prol dos direitos LGBT, como o representante à época da presidência da República e coordenador-geral de Promoção de Direitos LGBT da Secretaria de Direitos Humanos, Gustavo Bernardes, que declarou: “Nós achamos esse caso emblemático para o enfrentamento da homofobia no Brasil" (JÚRI..., 2013).

Diego Athayde foi absolvido pelo Conselho de Sentença, enquanto Ricardo foi condenado a 14 anos de prisão em regime fechado. A defesa do acusado ainda tentou tornar lgor culpado, alegando que o bailarino cometeu assédio sexual, que teria comportamentos inapropriados, e por ser uma figura excêntrica. Para esses advogados, Igor é praticamente um algoz de si mesmo; além disso, eles elevaram a homofobia de Ricardo a um ato de bravura e heroísmo de um pai em defesa de seu filho. No entanto não há bravura, tampouco heroísmo num crime de ódio, covarde, prevaricado e em vias de esquecimento e obsolescência pela Justiça. 


\section{Como o Estado e suas instituições de segurança pública e judiciais se manifestam ante os crimes contra LGBTs}

A violência contra LGBTs é um fenômeno social presente na realidade brasileira em todas as esferas da vida cotidiana, e sua propagação ultrapassa os limites de classe, gênero, raça e geração. Ela é caracterizada, portanto, como uma espécie de fenômeno multidimensional e multicausal, se instalando nas mais diversas camadas que compõem a sociabilidade humana em uma sociedade marcadamente patriarcal.

A inexistência, até junho de 2019, de uma tipificação criminal no Código Penal Brasileiro (CPB) a respeito de crimes por discriminação el ou preconceito contra pessoas LGBT inviabilizou até pouco tempo a indicação oficial da LGTBfobia nos crimes cometidos em tais circunstâncias. No entanto, isso não impediu as autoridades de fundamentar um inquérito ou uma denúncia contemplando conceitos e análises que abordassem essa percepção e esse entendimento.

Nessa perspectiva, os dados coletados a partir dos relatórios dos três inquéritos policiais demonstram essa fragilidade da lei brasileira quando neles a conclusão não enfatiza os motivos centrais do assassinato, restando como qualificadora o inciso I do $\S 2^{\circ}$ do artigo 121 do CPB: "mediante paga ou promessa de recompensa, ou por outro motivo torpe" (BRASIL, 1940, grifo meu). Fica evidente a fragilidade dos argumentos nos inquéritos e relatórios acerca de uma visão crítica quanto ao cometimento dos crimes. Essas instituições ainda operam de forma frágil e pouco profunda quando a linha argumentativa aponta para debates que abordam os gêneros e as sexualidades. A seguir, demonstro como as instituições policiais e judiciais se manifestaram quanto à motivação dos crimes relatados anteriormente.

\section{Os inquéritos policiais}

$\bigcirc$ inquérito policial, por ser o primeiro documento que relata o crime, é substanciado pela investigação policial nas primeiras horas do fato, como também pelo relato de testemunhas diretamente relacionadas ao ocorrido. Nesse sentido, ele pode carecer de informações e análises mais complexas por não ter se iniciado ainda uma investigação mais profunda.

Nenhum dos três inquéritos apresentou qualquer indicação que constituísse cabalmente uma intenção LGBTfóbica dos crimes; porém, alguns delegados (responsáveis pela produção desse documento) apontaram 
informações que podem levar a interpretações de que houve, sim, homofobia e, portanto, abjeção contra diversas características (corporais e comportamentais) das vítimas, em especial a expressão de suas sexualidades.

Exclusivamente no inquérito do crime contra Dalva e Camila, o delegado, ainda na fase inicial de investigação e na oportunidade de pedir a prisão temporária dos indiciados, menciona diretamente o termo "homofóbicos" em suas análises. Por outro lado, há uma observação um tanto ou quanto anedótica: parece haver uma dúvida ou receio de declarar abertamente que as duas eram travestis, então a autoridade policial opta por chamá-las de "rapazes", mesmo citando em parênteses que são travestis. No inquérito da Polícia Civil consta:

Trata-se o caso em tela, da prática de crime de Duplo Homicídio Qualificado, onde quatro pessoas, imbuídos de sentimentos homofóbicos, resolveram ceifar a vida de dois rapazes (travestis) como forma de demonstração de poder, imposição do medo e dominação. (GOIÁS, 2013, p. 93, grifo meu).

Entretanto, no relatório conclusivo do inquérito, o mesmo delegado resolve alterar o termo "sentimentos homofóbicos" por "sentimentos torpes e vil". Presumo, na melhor das hipóteses, que essa troca foi feita para dar ênfase à qualificadora "motivo torpe" do CPB, uma vez que não havia a qualificadora "homofobia". É intrigante a alteração, mas não posso afirmar com evidência o motivo, apenas o fato:

se deu por força de intolerância dos autores em aceitar a opção sexual das vítimas, bem como, imbuídos de sentimentos torpes e vil, resolveram ceifar a vida de dois rapazes (travestis) como fim único de demonstração de poder, imposição do medo e dominação do território [...]. (GOIÁS, 2013, p. 118, grifo meu).

No inquérito que trata do assassinato do menino Alex, o delegado questiona acerca dos hematomas no corpo do menino, e o pai então confessa que as agressões foram desferidas por ele como forma de corrigir as má-criações do filho, mas principalmente porque este tinha "trejeitos afeminados". Mesmo ante tal declaração, o delegado expressa que o comportamento "desobediente" do filho foi o motivo do espancamento que o levou à morte, sem vincular os "trejeitos afeminados" com a "desobediência": 
Ressalta-se que o INDICIADO afirma ter notado que o filho apresentava trejeitos afeminados, e por esse motivo aplicava alguns corretivos no menor, tendo, inclusive, aplicado no menor outras surras [...]. A afirmação do autor de que espancou seu próprio filho porque esse não era obediente, indubitavelmente, configura a qualificadora do motivo fútil, um motivo totalmente desproporcional à violência perpetrada. (RIO DE JANEIRO, 2014, p. 35, grifo meu).

Fica nítido que o delegado não fez uso analítico da informação, tampouco explorou a expressão dita pelo pai ("trejeitos afeminados") como condutora de preconceito contra a criança assassinada. Preferiu utilizar a "desobediência", de forma generalizada e pouco apurada, mesmo reconhecendo a desproporcionalidade entre os atos de infração do filho e as "correções" do pai, ou seja, os socos e pontapés que laceraram o fígado do menino.

No que diz respeito ao inquérito do bailarino Igor Xavier, esse documento tem elementos bem singulares quando comparado aos outros dois, primeiro porque se distancia do caso de Dalva e Camila em 10 anos, e do caso de Alex em 12 anos. A importância disso é que, em termos de avanços políticos, sociais e jurídicos, tanto o governo federal já havia instituído a Secretaria de Direitos Humanos, que abarcava a subsecretaria de direitos LGBT, quanto, no âmbito do poder judiciário, já tínhamos alguns marcos legais na legislação, que incorporou direitos de pessoas homossexuais. Isso revela indubitavelmente mudanças nos valores sociais e culturais da sociedade brasileira, que em 2002 ainda eram lacunosos.

Dessa forma, não consta no inquérito nada que aponte uma atitude ou motivos homofóbicos por parte do autor. Todavia, é um processo criminal que, exatamente por essas características, redundou no clássico contraponto aos insumos das diversidades sexuais, ou seja, justificativas morais contra a homossexualidade da vítima.

Por diversos momentos, o delegado se nega a acreditar nas narrativas dos indiciados, inclusive por serem estes as únicas testemunhas e, ao mesmo tempo, os envolvidos como praticantes do crime. Ainda com posicionamento crítico em relação às declarações proferidas pelos indiciados, o relator do inquérito não menciona nada em relação à homofobia que vitimou Igor Xavier. Não faz menção às declarações moralistas e preconceituosas que os acusados fizeram contra a vítima. Não há nenhuma associação entre a homossexualidade de lgor e a rigorosidade desproporcional do ato de Ricardo. 


\section{A denúncia do Ministério Público}

O entendimento sobre os corpos das vítimas é pautado pelo Ministério Público dos estados de Goiás e Minas Gerais como o de qualquer outro corpo violentado; já o promotor do Ministério Público do Rio de Janeiro é um pouco mais incisivo na alegação de motivação subjetiva de homofobia do crime. Nos dois primeiros, não há uma distinção ou uma apuração mais intensa de que tais corpos foram suplantados pela razão de não corresponderem aos padrões de gênero hegemônicos. São insuficientes ou inexistentes os argumentos das promotorias que desvelassem a orientação sexual e a identidade de gênero como centrais nos assassinatos. A ausência de instrução sobre crimes de conotação LGBTfóbica nos processos é uma deficiência sistêmica jurídica? Ou essa negligência é em razão do preconceito institucional? O que há é uma retroalimentação dos dois pontos, pois o Estado brasileiro não propicia para suas instituições públicas, independentemente da ordem de serviço, uma possibilidade de conhecimento crítico que rompa com a ignorância e o preconceito.

No assassinato das duas travestis, inicialmente o MP-GO denomina a vítima Camila ainda como "Camila de Tal", enquanto Dalva é nomeada com o seu nome civil, "José Dalvanei". É perceptivel o descuido por parte da promotoria ou mesmo a falta de interesse em entender que as vítimas, por serem travestis, se reconheciam como mulheres, por isso a adesão aos nomes sociais "Dalva" e "Camila". Portanto, já de início o MP-GO se isenta de um entendimento diferencial a respeito da identidade de gênero de Dalva e Camila.

No relatório de alegação final, a promotoria de Justiça finaliza o documento justificando a qualificadora "motivo torpe" como "desentendimento entre a acusada Carlinda e as vítimas horas antes do crime" (GOIÁS, 2013, p. 462). Logo, é demonstrado nessa parte final do relatório do Ministério Público que o crime brutal contra Dalva e Camila foi considerado torpe, banal, por ter sido fruto de uma discussão, um desentendimento frívolo entre as vizinhas. Afirmar que o crime foi em razão da condição de travestilidade de Dalva e Camila é majorar a compreensão de que existiu transfobia. $O$ contrário disso é tanto invisibilizar a identidade das vítimas quanto reduzir o grotesco crime a "picuinhas" de vizinhos.

No caso de Alex, o Ministério Público do Estado do Rio de Janeiro (MPRJ) é um pouco mais realista e justo com a condição da vítima. Entendendo que o menino apresentava um comportamento "afeminado", 
o promotor foi bastante enérgico nas críticas a quem considerasse tal comportamento como equívoco de gênero ou desvio moral. Assim, o promotor do caso apresentou esse dado como condicionante da motivação que levou o pai (réu) a espancar seu filho.

Em sua alegação final o promotor aponta, mesmo não usando o termo "homofobia", que as ações que caracterizam a repulsa contra homossexuais ou contra meninos com "jeito de menina" ou "afeminados" foram determinantes para a execução do pequeno Alex:

Especificamente em relação à qualificadora subjetiva, salienta-se que o próprio acusado, durante seu interrogatório em Juízo, afirmou que o réu 6 "andava rebolando, igual menina mesmo", o que o levava a "corrigi-lo", transparecendo, assim, que a motivação do crime foi a descrita na exordial. (RIO DE JANEIRO, 2014, p. 274, grifo meu).

A exordial à qual se refere o trecho acima é o relatório de denúncia apresentado pelo MPRJ em 14 de março de 2014, um mês após o crime. Fica mais evidente que a qualificadora do motivo "torpe" ou "fútil" do crime foi exclusivamente o fato de a vítima ser considerada "afeminada" pelo assassino e não se conformar no gênero masculino. Nas palavras do assassino, não se comportar como um "homenzinho" deve ser uma conduta banida e punida com a própria vida: "a motivação foi torpe, eis que o denunciado constantemente espancava a vítima para fins de corrigi-lo, pois entendia ser o menino 'afeminado', e bradava que não admitiria ter filho 'gay', preferindo vê-lo morto" (RIO DE JANEIRO, 2014, p. 2A, grifo meu).

O MPRJ, durante o julgamento final, também fez uma boa apresentação dos fatos e inseriu o espancamento do garoto como fator central para a condenação do réu, vinculando a agressão à suposta homossexualidade atribuída ao filho:

P [Promotor]: O seu filho tinha jeito afeminado?

A [Alex André]: Tinha, sim, senhor.

$\mathrm{P}:$ O que ele fazia pra ser afeminado, me fale aí?

A: Ele andava rebolando, brincando lá com as maquiagens das minhas filhas...

$\mathrm{P}$ : Ele falava que queria dançar a dança do ventre?

A: "Queria" dançar a dança do ventre não, ele "chegou" a dançar a dança do ventre!

$P:$ Ah, ele dançou? E o senhor achou o que disso?

6 Conforme relatório oficial, consta a palavra "réu", mas tenho convicção que foi um erro de digitação e de que a palavra correta deveria ser "vítima". 
A: Chamei ele, conversei com ele, falei que aquilo ali não é jeito de homem, que homem não fica assim... (informação verbal)?

Ainda que o representante do MPRJ não faça uso de insinuações diretas sobre a homofobia do pai, fica comprovado que todo o seu argumento é construído com base na repulsa de Alex André pelo "comportamento afeminado", contribuindo, assim, para a configuração do crime com motivações LGBTfóbicas.

Com relação ao crime contra Igor Xavier, como já mencionado, é um caso particularizado e diferenciado dos demais por tratar de um acusado com significativo poder político e econômico na região, que cuidou de protelar o julgamento com a execução de várias liminares em prol de sua defesa, sendo quase todas elas acatadas pelo Tribunal de Justiça de Minas Gerais.

No que tange à denúncia apresentada pelo Ministério Público de Minas Gerais (MPMG), embora contundente nos pedidos de prisão preventiva do acusado, não há um fulcro relacionado aos motivos que agravam a denúncia, ou seja, o sentimento homofóbico que moveu o assassinato. Isso é posto ainda na fase de investigação, quando o órgão oferece a denúncia:

\footnotetext{
Segundo consta nos autos, o denunciado Ricardo teria levado a vítima para sua casa, onde já se encontrava o filho e segundo denunciado, Diego. Embora não se saiba ao certo os motivos da ida, há rumores de que existiria certa afinidade entre a opção sexual tanto da vítima quanto de Ricardo, sendo que este, muito provavelmente, foi o fator motivador da visita. (BRASIL, 2016, p. 104-105, grifo meu).
}

Nas alegações finais, o MPMG não cita absolutamente nada que integre um argumento relacionado à motivação preconceituosa do acusado contra a vítima, uma vez que o primeiro alega que matou lgor por este assediar sexualmente Diego, filho de Ricardo; tampouco reitera o argumento inicial exposto no trecho acima. $\bigcirc$ Ministério Público não consegue impingir um argumento que tanto se contraponha à única narrativa dos fatos, apresentada exclusivamente pelos denunciados (já que não há relatos de testemunhas oculares sobre o caso, restando ao processo apenas a versão dos indiciados), quanto propague uma causa plausivel para estabelecer um agravante qualificado contra o assassino, restando, portanto, uma denúncia frágil nos termos de que o motivo "fútil" fora um "desentendimento banal":

7 Depoimento (em vídeo) de Alex André Moraes Soeiro concedido em 29 de julho de 2015, no Rio de Janeiro. 
[...] o crime ocorreu por motivo fútil, já que a partir de um desentendimento banal, sem importância, ocorrido após longo período de permanência amistosa no local dos fatos, o primeiro [Ricardo] e segundo [Diego] denunciados acabaram por ceifar a vida da vítima. (BRASIL, 2016, p. 5, grifo meu).

Nesse relatório fica outra vez nítido o silenciamento e a indiferença com o modo como mais um jovem homossexual foi assassinado. A crueldade e a frieza do ato, assim como a incompetência dos operadores da lei, implicam apontar essas instituições como negligentes e preconceituosas com relação à orientação sexual da vítima.

\section{O discurso sobre os corpos}

Num primeiro momento de análise dos processos, os dados levaram a uma reflexão, mediada pelas teorias sobre os corpos, sobre como estes foram vilipendiados, destituídos de suas identidades e, portanto, desvalorados para uma vida possível em sociedade. Depois disso, ao me aproximar das leituras e interpretações dos discursos dos representantes institucionais (da Polícia Civil, dos Ministérios Públicos e dos Tribunais de Justiça) que se manifestaram, cada um em sua respectiva instância representativa, percebi um salto paradigmático a respeito desses corpos. Refiro-me ao fato de como o corpo, de modo sutil, cede sua centralidade enquanto alvo preferencial da violência LGBTfóbica para o comportamento supostamente inapropriado de LGBTs.

Mesmo sendo o corpo a matéria a ser punida, ele só o é devido a um comportamento que desestabiliza o ordenamento das leis impostas aos sexos e aos gêneros. $O$ Estado pode até proteger, através de suas leis, o corpo e a vida como elementos invioláveis. Porém, quanto aos comportamentos, sobretudo os comportamentos ditos "inadequados" de pessoas LGBT, não há nenhum respaldo legal que assegure o direito de se "comportarem como lésbicas, gays, bissexuais, travestis e transexuais". Logo, parece haver um deslizamento nesse âmbito institucional do corpo abjeto para o comportamento abjeto (o mau, o nocivo, o anormal, o repugnante), que acaba por inverter o lugar do réu e o da vítima, pois o comportamento dito abjeto começa a justificar os assassinatos. $\bigcirc$ comportamento passa ter centralidade na discussão e no debate entre as instituições, deixando, assim, o corpo em segundo plano (PEIXOTO, 2018).

Nessa leitura, foram o Alex "afeminado", a Dalva e a Camila que se "vestiam como mulheres" e o lgor gay, "atrevido e extravagante" que 
motivaram seus assassinos a se perturbarem diante de comportamentos tão abjetos. É aqui, no comportamento, que o poder patriarcal pode cravar sua estaca com vigor, sem ser repreendido pelo Estado, uma vez que não há, juridicamente, uma ordem sobre isso. Ao induzir que a punição do corpo seja deslocada para a punição do comportamento, fica anunciado que as possibilidades efusivas dos corpos, ou seja, seus comportamentos, correspondem ao que Judith Butler (2018) nomeia como "performance". Os comportamentos são as performances reificadas em corpos, que por sua vez acionam as performances de gênero como responsáveis por expressar e dar facticidade a tais comportamentos. A punição do comportamento que agora passa a ser executada nada mais é que a punição de uma performance dos gêneros considerados "desviados", os quais desafiam a realidade construída sobre corpos que foram determinados por sexos binários, a partir de um discurso biológico (BUTLER, 2018).

essencialismo ou naturalismo imposto à díade sexo/gênero disputa com uma performance que corrompe um discurso ontológico e hegemonicamente estabelecido. Assim, os comportamentos que rompem com o determinismo biológico estão potencialmente sujeitos a punições das mais variadas. Enfatizo que, ainda que os corpos sejam o alvo material da violência, são as performances dos comportamentos "desviantes" que são aviltadas. Desse modo, nos processos analisados, o discurso em torno dos crimes não é apenas sobre os corpos, mas os assassinos também são afetados pela estética (pelo comportamento) do outro. Não há mais a materialidade dos corpos em questão, e sim suas performances abjetas de gênero.

Em Quadros de guerra: quando a vida é passivel de luto?, Butler (2017) demonstra que a sociedade contemporânea valida determinados corpos "comportados" em detrimento daqueles irreconheciveis no paradigma social. A autora aponta uma análise crítica da política de reconhecimento dos individuos, na perspectiva de quem e qual corpo merece ser defendido pelo Estado de uma situação adversa para a vivência plena. Ela aborda que a "indisciplina" promove um não reconhecimento de grupos, nações e parcelas da sociedade mundial, distinguindo quem merece de quem não merece viver, ou mesmo aqueles que despertam ou não uma comoção a partir da morte.

Assim, partindo dessas premissas, compreender os corpos expostos de Dalva, Camila, Alex e Igor requer um esforço de compreensão da totalidade social em que esses sujeitos estavam inseridos ao longo de suas vidas e no momento em que foram assassinados(as). As disciplinas e as normas morais 
que rondaram tais corpos os levaram ao extremo da punição, provocando o cerceamento de seu exercício pleno da vida. Ressalto ainda que os golpes contra esses corpos foram apenas um aspecto final de sua punição, através de ações de extrema violência (tais como decapitação, carbonização, laceração de fígado e traumatismos cranioencefálico e torácico). Os assassinatos são o produto final de uma engrenagem política que não se encerra na ação dos assassinos. A esfera política é apenas o lado exterior de um sistema mais amplo da sociedade, que envolve a dimensão pública e privada das relações sociais, as quais estruturam os valores que engendram os padrões dos corpos e da vida social como um todo.

A sociedade é também composta por instituições civis, como família, igrejas, movimentos sociais, organizações neonazistas e demais entidades formadas por coletivos identitários. Assim, uma parcela dessas instituições acaba por se desenvolver como aparelhos que atuam no disciplinamento e na punição dos corpos. Além disso, essas entidades podem contribuir para a repulsa, o cerceamento da liberdade e a violação de direitos humanos de LGBTs, obstruindo um conjunto de diretos sociais básicos dessas pessoas.

Em Vigiar e punir, quando Foucault (2012) investigou as etapas e os processos de disciplinamento dos corpos em instituições militares e escolares, o autor pôde comprovar minunciosamente a postura corpórea que provocava uma distinção qualitativa dos sujeitos. Um corpo político, advindo de uma economia do poder, produzia e reproduzia técnicas que comunicavam para toda a sociedade um modelo exato de como deveriam ser os comportamentos morais, tendo no corpo o espelhamento extraordinário desses valores morais e de todas as práticas de educação, bons modos e "civilidade". A díade "disciplina" e "poder" representava a dinâmica perfeita de produção de um corpo auspicioso para os padrões do sistema político-econômico-social hegemônico:

Técnicas sempre minuciosas, muitas vezes íntimas, mas que têm sua importância: porque definem um certo modo de investimento político e detalhado do corpo, uma nova "microfísica" do poder; e porque não cessaram, desde o século XVII, de ganhar campos cada vez mais vastos, como se tendessem a cobrir o corpo social inteiro. (FOUCAULT, 2012, p. 134).

A partir desse esboço é possivel compreender parcialmente, para além dos fatos descritos nos processos criminais, como e por quais fatores as ações e as mentalidades dos assassinos foram orientadas. Em dois dos três 
casos - de Igor Xavier e Alex -, há uma forte tendência nos argumentos de defesa dos acusados de desmoralizar os corpos que eles abateram, tornando-os (as vítimas) distintos de uma moralidade adequada à norma e, por isso, passiveis de morte.

\section{Conclusão}

Todos os acusados e a acusada dos três processos analisados neste estudo se tornaram réus e, consequentemente, foram condenados e condenada por júri popular em suas respectivas comarcas - com exceção de Diego Athayde, que foi julgado e absolvido. No entanto, isso não significa que a "justiça foi feita", cumprindo seu papel de bastião do direito, da legalidade civil e da ordem pública social; tampouco expressa que as penas imputadas aos réus e à ré afetarão substancialmente o fenômeno social da violência contra as pessoas LGBT, desestabilizando-o.

Destaco que não parti de uma ideologia de criminalização acrítica da violência contra LGBTs ou de uma percepção dessas pessoas exclusivamente como vítimas ante a supremacia heterossexual e binária de gênero. A violência é um aspecto do longo processo de construção de valores arraigados na estrutura do sistema patriarcal e sexista, interseccionado com o sistema capitalista, e pode levar a luta LGBT a um lugar estanque e de não deferência de suas vidas.

Há, porém, um elemento um tanto turvo e pouco explícito no sistema jurídico brasileiro, que é a morosidade no andamento de processos mediante a influência política e econômica que alguns individuos - acusados, réus ou mesmo já condenados - podem ter diante das instâncias jurídicas do país. As leis brasileiras privilegiam quem tem poder argumentativo para recorrer até às últimas instâncias antes de ser executada a prisão. Dessa forma, o aprisionamento, na maioria das vezes, só é de fato concretizado para quem não possui condições socioeconômicas (patrimônio material e familiar) favoráveis à constituição de um bom aparato de defesa. Soma-se a isso o fato de que significativa parte do corpo da magistratura, promotoria e defensoria no país é composta por pessoas que compartilham das mesmas condições socioeconômicas privilegiadas - tanto que é recente a presença de mulheres e negros no judiciário, por exemplo. Ainda assim, são quadros de uma elite econômica, de gênero e racial que ocupam esses lugares no judiciário brasileiro.

A lei pode até vir a ser aplicada a grande parte das pessoas, mas seu cumprimento difere conforme a classe, o gênero e a raça do(a) condenado(a). 
Por esse motivo, pensar a criminalização da violência contra LGBTs requer muito mais que a criação da tipificação criminal do "LGBTcídio". É necessário que haja, em paralelo à punição pelo crime, um longo e contínuo serviço de educação com vias à transformação dos valores morais sexistas nos diversos setores da sociedade civil e do Estado. Berenice Bento (2017) aponta que - Estado brasileiro vive um "mito da democracia às violências sexual e de gênero", ou melhor, uma "LGBTfobia cordial", porque enquanto são tolerados alguns corpos e comportamentos de pessoas LGBT que estão justificados pelo paradigma estético e moral vigente, outros são cruelmente eliminados.

Nesse sentido, o Estado apresenta-se como responsável por tais deficiências no interior de suas instituições, ou pior, o Estado pode caracterizar-se como coautor da violência por meio da omissão nos casos de violação dos direitos civis básicos de pessoas LGBT. A reflexão que fica é: o Estado brasileiro possui leis que asseguram e prezam pelo direito de defesa, contraditório e liberdade de pessoas acusadas até que se prove o contrário para todo(a) cidadão(ã)? E ainda: o Estado brasileiro garante a segurança das vidas LGBT? Ou isso é um dos privilégios de quem sempre esteve na condição de ostentar o poder econômico, jurídico e social? Diante dos três casos aqui elencados, sem dúvida, a segunda hipótese soa mais verdadeira e, infelizmente, mais corriqueira tendo em vista cenários políticos cada vez mais corruptiveis, conservadores e moralistas como os atuais.

\section{Referências}

BENTO, B. Transviad@s: gênero, sexualidades e direitos humanos. Salvador: EDUFBA, 2017.

BRASIL. Ministério da Justiça. Decreto-Lei n 2.848, de 7 de dezembro de 1940. Código Penal. Diário Oficial da União, Rio de Janeiro, p. 2391, 31 dez. 1940.

BRASIL. Superior Tribunal de Justiça (6. Turma). Recurso Especial 1585130/MG (2016/0061147-7). Relator: Min. Nefi Cordeiro, 3 de março de 2016.

BUTLER, J. Quadros de guerra: quando a vida é passível de luto? Tradução de Sérgio Tadeu de Niemeyer Lamarão e Arnaldo Marques da Cunha. Revisão de tradução de Marina Vargas. Revisão técnica de Carla Rodrigues. 3. ed. Rio de Janeiro: Civilização Brasileira, 2017. 
BUTLER, J. Os atos performativos e a constituição do gênero: um ensaio sobre fenomenologia e teoria feminista. Tradução de Jamille Pinheiro Dias. Caderno de Leituras, Belo Horizonte, n. 78, p. 1-16, 2018.

FOUCAULT, M. Vigiar e punir: nascimento da prisão. Tradução de Raquel Ramalhete. 40. ed. Petrópolis: Vozes, 2012.

GOIÁS. Tribunal de Justiça do Estado de Goiás. Comarca de Novo Gama. Autos do processo n 201300801381. Novo Gama: TJGO, 2013.

JÚRI condena Ricardo Atayde pela morte de bailarino no Norte de MG. G1, Rio de Janeiro, 27 ago. 2013. Disponivel em: https://glo.bo/2Vg6Sg9. Acesso em: 17 out. 2013.

KRISTEVA, J. Poderes de la perversión: ensayo sobre Louis-Ferdinand Céline. Tradução de Nicolás Rosa. México: Siglo XXI, 2006.

MBEMBE, A. Necropolítica. Tradução: Renata Santini. Arte \& Ensaios, Rio de Janeiro, n. 32, p. 122-151, 2016.

RIO DE JANEIRO. Tribunal de Justiça do Estado do Rio de Janeiro. Processo $n^{0}$ 0058899-95.2014.8.19.0001. 1 Vara da Capital. Rio de Janeiro: TJRJ, 2014.

PEIXOTO, V. B. Violência contra LGTBs no Brasil: a construção sóciohistórica do corpo abjeto a partir de quatro homicídios. 2018. Tese (Doutorado em Sociologia) - Universidade de Brasilia, Brasilia, DF, 2018.

Recebido em abril de 2020.

Aprovado em junho de 2020. 